\title{
A tale of two co-ops in two cities
}

\author{
Leah Halliday $a *$ and Michèle Foster ${ }^{b}$ \\ University of Louisville
}

Submitted January 17, 2019 / Revised March 30, May 10, and July 1, 2019, and January 26, 2020 /

Accepted July 3, 2019 / Published online February 28, 2020

Citation: Halliday, L., \& Foster, M. (2020). A tale of two co-ops in two cities. Journal of Agriculture, Food

Systems, and Community Development, 9(2), 239-254. https://doi.org/10.5304/jafscd.2020.092.005

Copyright (C) 2020 by the Authors. Published by the Lyson Center for Civic Agriculture and Food Systems. Open access under CC-BY license.

\begin{abstract}
Conceived in support of the Louisville Association of Cooperative Economics (LACE), this paper presents case studies of two different food cooperatives serving communities of color. After establishing a brief history of food cooperatives, we explore the expansion efforts of Seward Community Coop, a long-standing and well-established cooperative in a predominantly White area of Minneapolis, Minnesota, into a more diverse area of the city. Next, we explore the Mandela Grocery Co-op in Oakland, California, a relatively new, worker-

a* Corresponding author: Leah Halliday, Doctoral Candidate, Department of Middle and Secondary Education, College of Education and Human Development, University of Louisville, Louisville, Kentucky, USA; leah.halliday@louisville.edu

${ }^{\mathrm{b}}$ Michèle Foster, Henry Heuser Jr. Endowed Chair for Urban Education Partnerships and Professor, Department of Early Childhood and Elementary Education, College of Education and Human Development, University of Louisville, Louisville, Kentucky, USA.
\end{abstract}

owned cooperative. We then discuss several points to consider in the development of new co-ops that emerge from these cases.

\section{Keywords}

Food Cooperatives, Co-ops, Food Justice, Community Development

\section{Introduction}

Food cooperatives (commonly known as co-ops), like genius in Edison's view, are 1\% inspiration and 99\% perspiration. Reyes (2015) classes this inspiration into two major ideologies. The first type of coop is primarily designed to "meet a community desire for organic and natural food" (Reyes, para. 6). The other type, aligned with the food justice movement, is primarily focused on promoting access to full-service grocery stores in underserved

\section{Funding Disclosure}

This research was funded by a Transdisciplinary grant from the University of Louisville Social Justice Consortium. 
areas, with a complementary goal of building community wealth and ownership. ${ }^{1}$ While both types of co-op rely on hard work and dedication, these distinct foundations are rooted in history as well as the current social, economic, political, and geographical contexts. Thus they may contribute to the distinct challenges and opportunities individual food co-ops encounter. Below, we present case studies of two significantly different food co-ops that represent these ideological distinctions. Seward Community Co-op, a well-established, natural-food focused, consumer-owned co-op in Minneapolis, Minnesota; and Mandela Grocery Co-op, a recently developed, food-justice focused, African-American worker-owned co-op in Oakland, California. The two case studies suggest that the ideological focus of a co-op, as well as its temporal and geographic context, can greatly influence the work that will define it and help it flourish.

\section{Literature Review}

Grocery co-ops in the United States range in size and scope but are generally founded on principles formally outlined by the Rochdale Equitable Pioneers Society. In 1843, following a failed worker strike, this group of textile workers in Rochdale, England, sought another path to economic strength: a community-owned grocery store (Zimbelman, n.d.). Over the years, the grocery coop movement in the U.S. has experienced waves of popularity and success: first in the 1920s and '30s, again in the 1960s and '70s, and now, with the current wave beginning in the early 2000s (Kauffman, 2017b). Most second-wave and current examples grew from small community movements: groups of friends and neighbors coming together to pool resources and meet their needs (Kauffman, 2017b). Jessica Gordon Nembhard (2014), a historian and expert on African American cooperatives, traces the roots of African American co-ops to the era of slavery in America, during which Black communities "organized myriad strategies of emancipation" (p. 33). According to Nembhard, in addition to the common principles of cooperation, Black co-ops were born of economic necessity and survival, and relied on ideas of self-help and racial solidarity.

As small societies that are formed to meet the needs of members, co-ops have founding ideologies that are evident in day-to-day operations as well as in challenges and areas of opportunity. Whereas most cooperative communities founded in the second wave of cooperative development in the U.S. were championed by members of a White, college-educated counterculture (Kauffman, 2017b) who often pooled finances to gain access to highquality bulk and organic food choices, the earliest African-American co-ops often relied on what Nembhard (2014) calls "sweat equity" when money was scarce. The historical distinction in resources between groups who come together to form cooperative communities set a precedent for a distinction that remains today between worker-owned and consumer-owned cooperatives. Exacerbating historical financial challenges, early African American cooperatives, as avenues of economic empowerment, often faced sabotage by White supremacists intent on their failure (Nembhard, 2014), while White cooperative societies, even those without extensive financial support, benefitted from the absence of systemic oppression and sabotage. The needs of the members necessarily influence the development and progression of food co-ops.

While the organizers who initiated the co-op resurgence in the 1970s in Minneapolis were relatively cash-poor, the social privilege of their communities helped them secure access to loans, free locations, and volunteer hours in their quest for "economic and ideological independence from supermarket chain stores" (Olsen, 1998, para. 2). Considering the differences in community problems, the risks and benefits associated with cooperative organizing, and the resources at their disposal, it is not surprising that the majority of cooperatives that survived the boom years of the 1970s were White and consumer-owned. As a result, many African Americans may not be familiar with the

\footnotetext{
${ }^{1}$ Reyes (2015) and many others in the field label underserved or food-insecure areas with no access to full-service grocery stores as "food deserts." We avoid that term in acknowledgement of the argument outlined in Atkinson (2016) that “'the 'desert imagery,' evoking an absence of life, puts emphasis on the lack of supermarkets rather than on the landscape of racial discrimination and poverty afflicting these communities" (p. 5).
} 
tradition of cooperatives within their communities or be aware that some of the early African American leaders suggested them as a solution or remedy for meeting needs and developing wealth within the community. As Nembhard (2014) points out, "Almost all African American leaders and major thinkers, from the most conservative to the most radical, have at some point promoted cooperative economic development as a strategy for African American well-being and liberation" (p. 213). As we discuss in the case study below of Seward Community Co-op, even some existing cooperative communities are unaware of the rich history of African American co-ops.

Despite the differences in ideological foci and the community resources and goals that inform them, both types of co-op might organize as a group of people who simply purchase goods together periodically without a dedicated physical space or without developing and running a regular storefront (Reid, 2012). Either type may inspire cooperatives that are consumer-owned, workerowned, or some hybrid of the two. Cooperatives of both types must decide to govern day-to-day operations and larger growth and development plans using strictly democratic collective management methods, more traditional corporate-style governance structures, or something in between (Kauffman, 2017b). Both must choose what products to purchase or stock and how to allocate profits or manage losses. From these decisions emerge many possible outcomes, from those with all the formality of a roadside stand to those that might be indistinguishable from a Whole Foods or Trader Joe's to the uninitiated (Neighboring Food Co-op Association, n.d.).

Indeed, the work of developing a co-op becomes something of a choose-your-own-adventure story, with each decision representing a tradeoff leading to a new set of options in a complex and ever-expanding balancing act among consumer preferences, owner demands, ideological foundations, and food costs. Reyes (2015) notes that "we have to be thoughtful about which needs we're trying to address and which models we're going to implement" (para. 7) and we found careful consideration to be the norm when we discussed these tradeoffs and priorities with co-op leaders for our case studies. We illustrate this balancing act of priorities in Figure 1.

Figure 1. Finding Balance Among Shareholder Values and Food Costs

\begin{tabular}{|c|c|c|c|c|}
\hline & $\begin{array}{c}\text { LOW-BUDGET } \\
\text { CONSUMER/OWNERS }\end{array}$ & $\begin{array}{c}\text { HIGH-BUDGET } \\
\text { CONSUMER/OWNERS }\end{array}$ & $\begin{array}{c}\text { FOOD } \\
\text { ACTIVIST CO- } \\
\text { OP IDEALS }\end{array}$ & $\begin{array}{l}\text { NATURAL } \\
\text { FOOD CO-OP } \\
\text { IDEALS }\end{array}$ \\
\hline $\begin{array}{l}\text { ORGANIC, FREE- } \\
\text { TRADE, } \\
\text { SUSTAINABLY } \\
\text { SOURCED FOODS }\end{array}$ & - & + & - & + \\
\hline $\begin{array}{l}\text { UIVING WAGE } \\
\text { FOR EMPLOYEES }\end{array}$ & + & - & + & - \\
\hline $\begin{array}{l}\text { COMMUNITY } \\
\text { REPRESENTATION } \\
\text { IN EMPLOYEES / } \\
\text { OWNERS }\end{array}$ & + & - & + & - \\
\hline $\begin{array}{c}\text { FAIR } \\
\text { PARTNERSHIPS } \\
\text { WITH } \\
\text { PRODUCERS/ } \\
\text { GROWERS }\end{array}$ & - & - & + & + \\
\hline
\end{tabular}


While the history of food cooperatives is surprisingly littered with conflict and even violent tension among proponents of the different ideologies (Olsen, 1998), an exploration of current thriving co-ops can be instructive, especially to those interested in how new or existing co-ops can engage in meeting the needs of communities in most urgent need of food security. As these case studies of the expansion efforts of the Seward Co-op in Minneapolis, Minnesota, and the birth and growth of the Mandela Co-op in Oakland, California, demonstrate, the ideological foundation supporting a coop will influence the direction of the hard work that will lead to its ultimate success, but passion, dedication, and respect for community are always a part of the equation.

\section{Methods}

The Louisville Association of Cooperative Economics (LACE) requested these case studies to guide them in the development of a communityowned grocery store. Funded by a Transdisciplinary grant from the University of Louisville Social Justice Consortium, these case studies were one of several research projects whose aim was to provide research for LACE. The association generated a list of food co-ops they were interested in learning more about, and from the larger list, selected two to be studied. The first phase of the research began in August 2018 with a comprehensive search of articles published about each co-op, general information about the locations, and other documents retrieved from the web (including information from each co-op's website). From this initial search, we developed a series of questions for each food co-op, in order to round out and give more context to the online research. In addition, we developed a set of questions that probed for information about funding and governance to best address the interests and concerns LACE expressed upon initiating the case studies. Abby Rogosheske, education and outreach coordinator at Seward Co-op, was the first to agree to an interview. We spoke with her by phone in September 2018. She then referred us to and connected us with Ray Williams, head of operations, and Liz Wozniak, head of human resources; we interviewed Mr. Williams and Ms. Wozniac together by phone a week later. We also interviewed worker-owner Adrionna Fike, of Mandela Grocery Co-op, by phone in October 2018.

\section{Seward Community Co-op: The Friendship Store, Minneapolis, MN}

\section{Today: Seward's Friendship Store}

Seward Community Co-op today is a thriving consumer-owned food cooperative with three locations. The focus of this case study is the Friendship Store, the brand's second full-service grocery, which opened in October 2015. The organization also includes the Franklin Store, an older, fullservice grocery in the Seward neighborhood where the co-op began, and The Creamery, the site of the administrative offices and distribution center that also boasts a full-service café. The Friendship Store is located at 317 East 38th Street, the primary business corridor in this part of the city, just between the Bryant neighborhood (a district named after American poet William Cullen Bryant), and the Central neighborhood (where musician Prince grew up; his feature film "Purple Rain" is set in this area) (Figure 2).

Understanding the context of the city and the two areas of Seward, and the Bryant and Central neighborhoods, in particular, helps to illuminate the implications of the expansion. Eleven communities in Minneapolis containing between 4 to 13 neighborhoods compose the city. Located in the Northeast not far from the University neighborhood, within walking and biking distance of the University of Minnesota, the Seward neighborhood and co-op is located in the part of the city known as the Longfellow area. Seward, where the original co-op is located, is one of the most politically liberal neighborhoods in Minneapolis. In this neighborhood, the Democratic-Farmer-Labor Party and Green Party are major political forces (Neighborhoods of Minneapolis, 2018). As illustrated in Figure 3 below, the population of Seward recorded in the 2010 census was $55.1 \%$ White and $33.2 \%$ African-American, with no other category totaling more than $3.7 \%$. Wealth is also important in understanding the neighborhood: the percentage of residents with an income below the poverty level was $25.6 \%$, while $48.6 \%$ of residents reported income 


\section{Figure 2. Locations of the Seward Cooperatives (Seward Community Co-op, the Franklin Store; Creamery Café; and the Friendship Store) ${ }^{a}$}

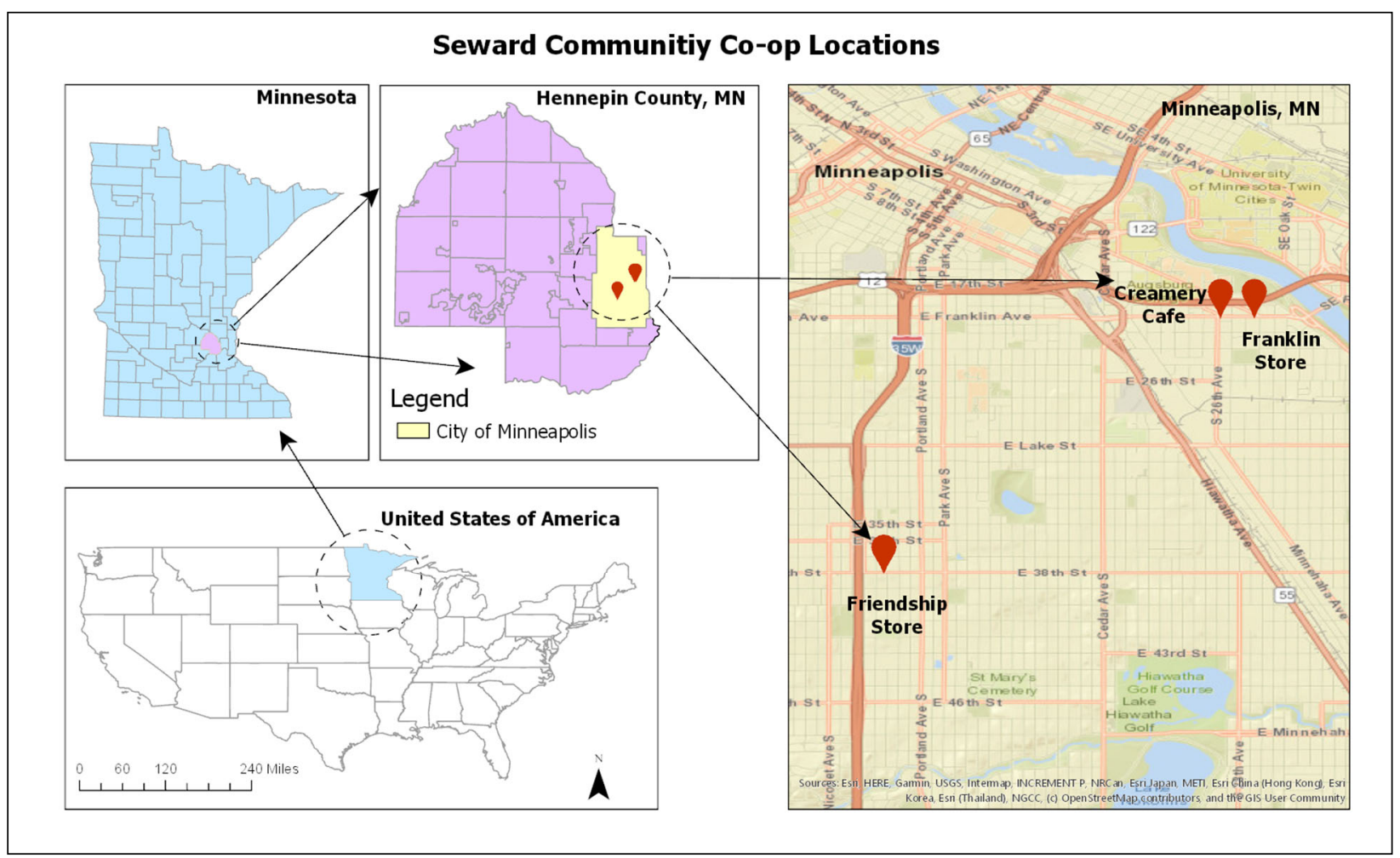

Sources: Fitzpatrick (2012); Minnesota Department of Transportation $(2017,2018)$.

a Maps were created by using ArcGIS software by Esri. ArcGIS and ArcMap ${ }^{\mathrm{TM}}$ are the intellectual property of Esri and are used herein under license. Copyright @ Esri. All rights reserved.

of $200 \%$ or more above the poverty level (Minneapolis Neighborhood Profile: Seward, 2011).

Bryant and Central are located in the area referred to as the Powderhorn Community (Neighborhoods of Minneapolis, 2018). In 2010, the combined population of the Bryant and Central neighborhoods was 11,140 -about $2.9 \%$ of the city's total population. As indicated in Figure 3, at the 2010 Census, the populations of Bryant and Central combined were $40.3 \%$ Hispanic or Latino, $27.3 \%$ Black or African American, and 23.4\% White, with all other recorded categories amounting to $4 \%$ or less each. The percentage of residents with an income below the poverty level in Bryant and Central was $30.3 \%$, while $38.8 \%$ of residents reported an income of $200 \%$ or more above the poverty level (Minneapolis Neighborhood Profiles Bryant, 2011, \& Minneapolis Neighborhood Profile: Central, 2011). So, while Seward Commu- nity Co-op's expansion did not extend beyond Minneapolis, the opening of the Friendship Store represents a major shift in context, a point that we discuss in more depth below.

Seward's commitment to diversity, equity, and inclusion drives efforts at the Friendship Store to make the co-op a full and beneficial part of the community. Seward accepts payment via the Supplemental Nutrition Assistance Program (SNAP) and the Special Supplemental Nutrition Program for Women, Infants, and Children (WIC). Additionally, Seward's Nourish program provides an across-the-board 10\% discount to any shopper who qualifies for state or federal nutritional assistance, and it encourages community members enrolled in these assistance programs to shop at the co-op through advertising campaigns that stress the sentiment proudly blazoned on each Seward location: "Everyone Welcome." This welcome at 


\section{Figure 3. Comparative Racial Makeup of Minneapolis, Seward Neighborhood, and Bryant/Central Neighborhoods, Based on Data from the 2010 Census}

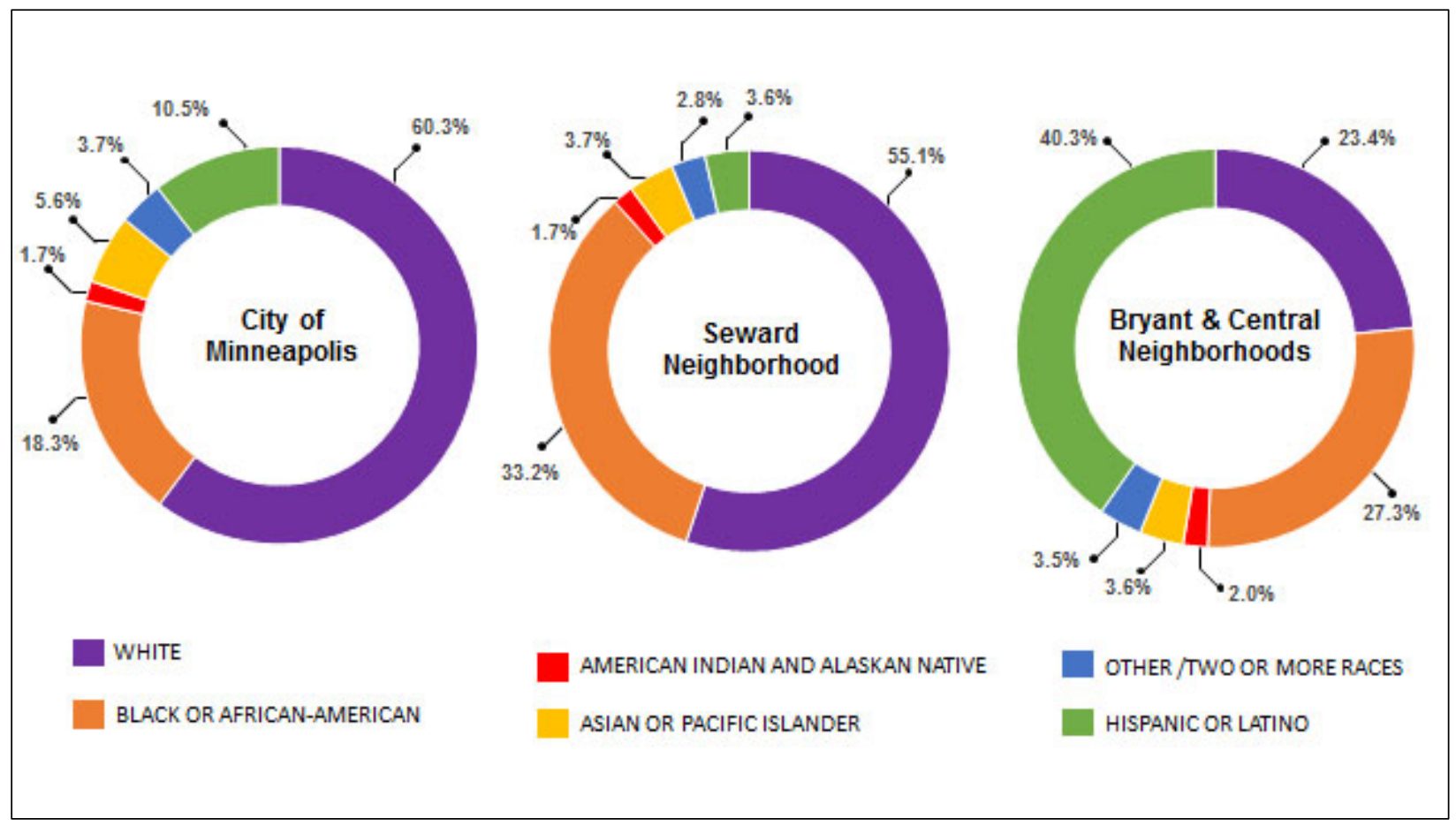

Sources: Minneapolis neighborhood profile: Bryant (2011); Minneapolis neighborhood profile: Central (2011); \& Minneapolis neighborhood profile: Seward (2011).

the Friendship Store goes beyond an invitation to shop. Even shoppers on tight budgets are welcome to become member-owners, thanks to the Nourish program's need-based assistance that offers the US $\$ 75$ membership fee to eligible shoppers for only US $\$ 15$ upfront, with the rest paid over time and with help of the annual co-op payout to owners in profitable years (A. Rogosheske, personal communication, September 10, 2018).

Seward's efforts to meet the needs of financially constrained shoppers include making food as affordable as possible at the Friendship Store by marking down prices on many bulk items and pantry staples to the absolute minimum profit margin. These items are indicated by a Nourish symbol on the tags. Nourish strives to ameliorate the higher costs associated with ethically and/or sustainably produced and sourced foods by offering courses on shopping at the co-op on a budget and cooking. The Friendship Store, like the other locations, includes classroom space where 4-5 classes are offered every month. Nourish 101 classes, for instance, feature basic scratch-cooking techniques and recipes that will feed a family of four for less than US $\$ 10$. At the time of this writing, in the early fall of 2018, classes and recipes included a cauliflower curry soup featuring seasonal ingredients, and Three Sisters soup, inspired by the Native American tradition of growing and harvesting corn, beans, and squash together (Seward Community Co-op, 2018).

In addition to the Nourish program, all the Seward stores participate in a round-up program that allows shoppers to round their purchase totals up to the nearest dollar, and the differences are collected and donated to a different local nonprofit every month. This program has allowed Seward to provide up to US $\$ 20,000$ per month to support less well-established organizations that share their member-owners' values (Seward Community Coop, n.d). Further, Seward's education and outreach efforts include frequently participating in and/or sponsoring various community events and a competitive grant program for other area organizations. 
Also important to its acceptance in the community, the Friendship Store's employees reflect the Central and Bryant neighborhoods. While the challenge of reaching this achievement is addressed later in this piece, the Friendship Store opened with over $60 \%$ of its employees representing people of color and over $50 \%$ living within one mile $(1.6 \mathrm{~km})$ of the store. Those numbers have fluctuated slightly, but remain right around $50 \%$ after three years. People enjoy coming in to shop and seeing their neighbors or church members working there (A. Rogosheske, personal communication, September 10, 2018). Seward's commitment to paying these workers a living wage, around US $\$ 15$ per hour in Minneapolis, further ingratiates the Friendship Store with the Central/Bryant communities (A. Rogosheske, personal communication, September 10, 2018).

Community members have also embraced the Friendship Store as member-owners and shoppers, leading to earlier-than-expected profitability. While many Seward owners lived in the area before the Friendship Store opened, over 1,000 new owners bought into the co-op in the first year, and the total number of member-owners now is between 18,000 and 19,000. Thanks to these new members and other shoppers, the Friendship Store became profitable in a year and a half, cutting the three-year projection the Seward board had determined at the project's onset in half. While the growth in sales has now leveled out across the board at Seward, the Friendship Store represents a financial and social success in the community in the eyes of the organization (A. Rogosheske, personal communication, September 10, 2018).

\section{Yesterday: The Conception of and Path to the Friendship Store}

Geographically, the Friendship Store is a mere two miles $(3.2 \mathrm{~km})$ west of the main Franklin branch. Despite this proximity, the communities are worlds apart, with differences in racial, cultural, and socioeconomic composition rooted in a history of red- lining and other racial discrimination (Lindeke, 2015b). For Seward Community Co-op, the histories of racial discrimination and co-ops in Minneapolis culminated in challenges to its efforts to bring the Friendship Store to fruition, despite the need for a grocery store in the area and the good intentions of everyone involved.

Seward Community Co-op is one of the few remaining co-ops from the tumultuous co-op scene in the '70s in Minneapolis. Olsen (1998) provides an overview of the drama and conflict, known in the area as "The Co-op Wars," that accompanied the surge of food co-ops in Minnesota during the second wave of co-op growth. At this time, several co-ops were founded in the Minneapolis-St. Paul area, some primarily dedicated to providing healthy foods and others dedicated not only to providing wholesome food but also to advancing explicitly political goals. ${ }^{2}$ In the predominantly Black community of Bryant, a food co-op begun by Moe Burton, a former Black Panther and avid community organizer, had an absolute focus on community empowerment and self-determination (Lindeke, 2015b). The competing agendas of these cooperatives broke out into a co-op war, with some of the groups attacking each other violently (Olsen, 1998). The co-ops that survived were those with a natural food orientation, including Seward, while the more overtly political co-ops died out, leaving the Bryant area without access to a fullservice grocery and likely with a skeptical view of co-ops developed outside the community.

While racial tensions and inequality in America are commonly associated with the Deep Souththe result of slavery and Jim Crow legislationracial inequality is not confined to the South. In fact, Minnesota is second to only Wisconsin in terms of racial inequality, as measured by multiple quality-of-life indicators and evident in rates of unemployment, income, homeownership, incarceration, and education outcomes (Wagner, 2017). For instance, Black people in Minnesota are 10 times more likely to end up in jail or prison than White

\footnotetext{
2 In addition to Olsen (1998), see these stories by Deacon Warner from Radical Roots for more on the political tensions that arose in the co-op community in Minneapolis in the 1970s: http://www.radicalrootsfilm.com/blog-1/2015/5/28/bryant-central-three-triesat-a-co-op; http:/ / www.radicalrootsfilm.com/blog-1/2015/5/28/minneapolis-mayors-husband-breaks-marxists-arm-defending-hisco-op-in-street-brawl; http://www.radicalrootsfilm.com/blog-1/2015/5/28/another-side-of-the-peoples-warehouse-takeover
} 
people. The median income for a Black household is US\$30,306, but for a White household it is more than double that at US\$66,979. According to data from both the Massachusetts Comprehensive Assessment System (MCAS) and the National Assessment of Educational Progress (NAEP), achievement gaps between White students and students of color in Minneapolis are large and to date immutable, despite prevalent high achievement scores(Wagner, 2017).

Against this backdrop of inequality in the city as well as the contention of the co-op wars, bringing a Seward expansion into Bryant was much more complex than one might have supposed at first glance. After all, Seward's Franklin Store was bursting at the seams, and initial internal research revealed that many of its members lived in the Bryant/Central area already. Further, Bryant/ Central residents needed access to the healthy food choices that Seward could provide. One group of area residents even approached Seward to advocate for a Bryant/Central branch. But challenges remained.

Seward's mistake, according to Rogosheske, was in assuming that this small group was representative of the community as a whole. Taking this group's request as a welcome to the neighborhood, Seward staff found themselves planning a new branch in an area where the residents would prove to be much more guarded than Seward had foreseen (A. Rogosheske, personal communication, September 10, 2018). As Rogosheske shares, not enough work had been done to understand the politics of the neighborhood and determine whether this group accurately represented the views of the neighborhood. "In retrospect," she shares, "That's community organizing 101" (A. Rogosheske, personal communication, September 10, 2018).

As it turned out, many Bryant and Central residents were wary of economic development in the area that could lead to gentrification, and they feared that even a nearby store would not alleviate problems in the area if local residents were unable to shop or work there (Boarini, 2013). The community members' wariness illustrates the complexity of the idea of access. For instance, Usher (2015) identifies five dimensions of access, and store loca- tion represents just one part of one of those dimensions. Community members in Bryant and Central knew that proximity to expensive groceries and inaccessible jobs would not help the most vulnerable in the community and might even cause harm by driving up property values. During the planning process, some Bryant/Central community members directly expressed concern about negative outcomes such as gentrification; costly or overpriced foodstuffs, particularly produce; a lack of job opportunities; and all-White management. These concerns were expressed at a meeting where questions were raised to which the co-op management issued written responses (Boarini, 2013).

Despite this effort by Seward to assure the community of its goodwill, many residents saw that they needed a seat at the table. At this point, two neighborhood organizations, the Bryant Neighborhood Organization (BNO) and the Central Area Neighborhood Development Organization (CANDO), had come together to get the communities engaged in the process of pushing back against Seward in an attempt to represent the communities' needs. They advocated for a community benefits agreement (CBA) that would hold Seward financially responsible if it did not deliver on its assurances to the community, and this became a bone of contention. Seward was hesitant to agree to fines or sanctions if they were unable, as they saw it, to hire the percentage of community residents demanded, pay the approximately US $\$ 15$ per hour living wage, or were otherwise to fail in their good-faith efforts to meet the needs of the community (Lindeke, 2015a). As Liz Wozniac, director of human resources at Seward explained, Seward saw the proposed CBA as a threat to the financial well-being of the organization as a whole, something Seward could not accept in light of its responsibilities to its current member-owners and loyal supporters from its 40-year history (L. Wozniac, personal communication, September 17, 2018). The neighborhood residents deeply felt their lack of leverage and could not fully credit the goodwill expressed by Seward, especially considering the historic tensions and a scarcity of employees of color that Seward explained as due to a scarcity in the pool of applicants (Boarini, 2013).

Development was almost certain to move for- 
ward, however, even without community buy-in, and neither Seward nor community leaders were satisfied. At this time, as Rogosheske recalls, Seward realized that genuine community organizing efforts were long past due, and they recruited LaDonna Sanders-Redmond to take the lead. With a background in food justice activism forged in the school systems of Chicago, Sanders-Redmond hit the ground running with a strong community organizing plan and some unlikely help from a zoning imperative. Since the plans to build were set to move forward, Seward needed signatures from every household within 1,000 feet of the new site to change the zoning of the location. Consistent with Sanders-Redmond's boots-on-the-ground approach, this zoning requirement meant knocking on doors. As Rogosheske puts it, being forced to knock on "every single door" in the neighborhood for permission to rezone was a blessing in disguise. Sanders-Redmond and her assistant were able to address not only zoning questions and concerns, but often even negative perceptions of co-ops. They found that many residents viewed co-ops as White spaces, or elite spaces, where only the wealthy could or would choose to shop (A.

Rogosheske, personal communication, September 10, 2018). ${ }^{3}$

In addition to speaking with families in their homes, Seward also took internal steps to address the community concern that the economic opportunities presented by the Friendship Store would not directly benefit the community. To attract diverse employees, particularly from the immediate neighborhood, Seward held a job fair for the new branch in a Bryant/Central community center. Further, Sanders-Redmond was able to move the needle toward the diverse hiring practices advocated for by community leaders by rethinking and rewriting some of the job descriptions that may have discouraged potential applicants who were unfamiliar with food co-ops. As Pagani (2016) explains, "The co-op added questions about cultural competency to its interview process and rewrote job descriptions to emphasize essential skills over experience" (para. 20). Sanders-
Redmond explained that job applicants might have been put off by co-op specific language: "But you don't need that to bag groceries.... You need to be attentive to detail, able to lift 50 pounds [23 kg], and have great customer service skills. We can teach you the difference between gluten-free and organic" (quoted in Pagani, 2016, para. 20).

In their continuing efforts, both SandersRedmond and Ray Williams, Seward's current head of operations, spoke at community events and churches. Sanders-Redmond's experience as a food justice advocate in multiple capacities helped bridge any lingering gaps from the ideological contention of the co-op wars as well as the widespread problem of food inequity. She served as the point person for questions and concerns of community members and brought her understanding of and focus on community education to bear through writing and outreach aimed at the Bryant/Central community. Williams stressed the lessons in humility that confronted Seward organizers throughout the process. He explained how going into a longstanding community and using language that often accompanies co-operative economic ventures, like "cultivating a community," was often received as insulting or condescending to the residents. Williams explains that negative pushback made listening to and engaging with community members a priority (R. Williams, personal communication, September 17, 2018). But time was running short to foster buy-in if the Friendship Store were to open both on schedule and with the community's support.

With Seward steadily working to earn support on the ground, yet another important mediating force joined the efforts just weeks before the Friendship Store was set to open. Elizabeth Glidden, a city council member who recognized the potential benefit of this project to the city, stepped in to bring leaders from CANDO, BNA, and Seward all together to try to find common ground in a series of professionally mediated meetings. These important meetings, in addition to the efforts of Sanders-Redmond, Williams, and others at Seward, helped the groups find common ground

3 See also Boarini (2013), Slocum (2007), and Zitcer (2015) for further discussion of perceptions of food co-ops as exclusionary and/or White spaces. 
in community commitments and a common language in which to communicate. This journey, and the coalescence of community around Seward's efforts to open the Friendship Store, reflect a wide range of the challenges, failures, and successes involved in bringing a grocery co-op to an economically and culturally diverse community that is wary of gentrification, despite its need for access to healthy food.

\section{Tomorrow: Continuing Challenges for the Friendship Store}

The tensions that emerged during the balancing of priorities have not disappeared entirely. Despite the classes and discounts the Nourish program supports, the cost of the locally sourced, organic foods favored by the co-op member-owners remains a barrier to full community support and use. In online user reviews on Yelp (n.d.-b) and in the Google business listing for the Friendship Store, the high price of food is a major and recurring theme. But, as Wozniac points out, food co-ops have a responsibility to everyone along the line: farmers, producers, workers, consumers, and owners (L. Wozniac, personal communication, September 17, 2018). She notes that the same people who advocate for lower prices will argue, often in the same breath, for higher wages for workers $(\mathrm{L}$. Wozniac, personal communication, September 17, 2018). Much of the co-op enterprise, then, becomes educating people on the real costs of food, or as Wozniac puts it, "telling the story of why" (L. Wozniac, personal communication, September 17, 2018). The process of fostering community support and providing education is ongoing. As Rogosheske sees it, it is Seward's explicit commitment to diversity, equity, and inclusion that will keep it on track: "We make mistakes all the time, but we always come back to that. This is our commitment. Through our successes and our mistakes, we hope we can learn and teach other people, and other co-ops from what we're doing" (A. Rogosheske, personal communication, September 10, 2018).

While the Friendship Store appears to be a thriving part of the Seward Community Co-op team now, its path to success reveals the particular challenges that an established cooperative can experience when branching out to meet the needs of an underserved area, despite having the capital and resources to sustain expansion.

\section{Mandela Grocery Co-op, Oakland, CA}

Next, we look at a relatively new co-op in another part of the country that, like Minnesota, already supports multiple grocery co-ops, but unlike Seward, had to make its way without financial backing from an established parent store: Mandela Grocery Co-op in Oakland, CA.

\section{Today: Small but Mighty}

Mandela Food Co-op, located in a small storefront just across the street from the West Oakland area's Bay Area Rapid Transit (BART) stop in a steadily gentrifying area, is entirely worker-owned and operated (Figure 4). The space is distinctly African American. From the art on the walls to the arrangement of products, the entire space is designed to reflect the African American community and African American ownership. All of the worker-owners are African American, and the worker-owners do everything that needs to be done for the co-op themselves. As Adrionna Fike, a worker-owner since 2012, explains, "We absolutely do not outsource" (A. Fike, personal communication, October 24, 2018). From negotiating prices with vendors to developing relationships throughout the community and beyond, to placing orders, stocking shelves, raising funds, conducting outreach and marketing, checking customers out and bagging groceries, the worker-owners do it all. When the co-op needed to do marketing research, the worker-owners themselves set out knocking on doors and conducting over 200 surveys, offering US $\$ 10$ gift certificates to community members whether they completed a survey or not. Despite the demands of the work, the store boasts only 10 employees, of whom seven are worker-owners and two are on track to become worker-owners; one employee, whom Fike says originally wanted simply to volunteer, works part-time at the co-op with no intention of buying in. While they do have a general manager, she is, according to Fike, egalitarian, and management of the store remains cooperative (A. Fike, personal communication, October 24, 2018). 


\section{Figure 4. Mandela Grocery Co-op Location Mapa}

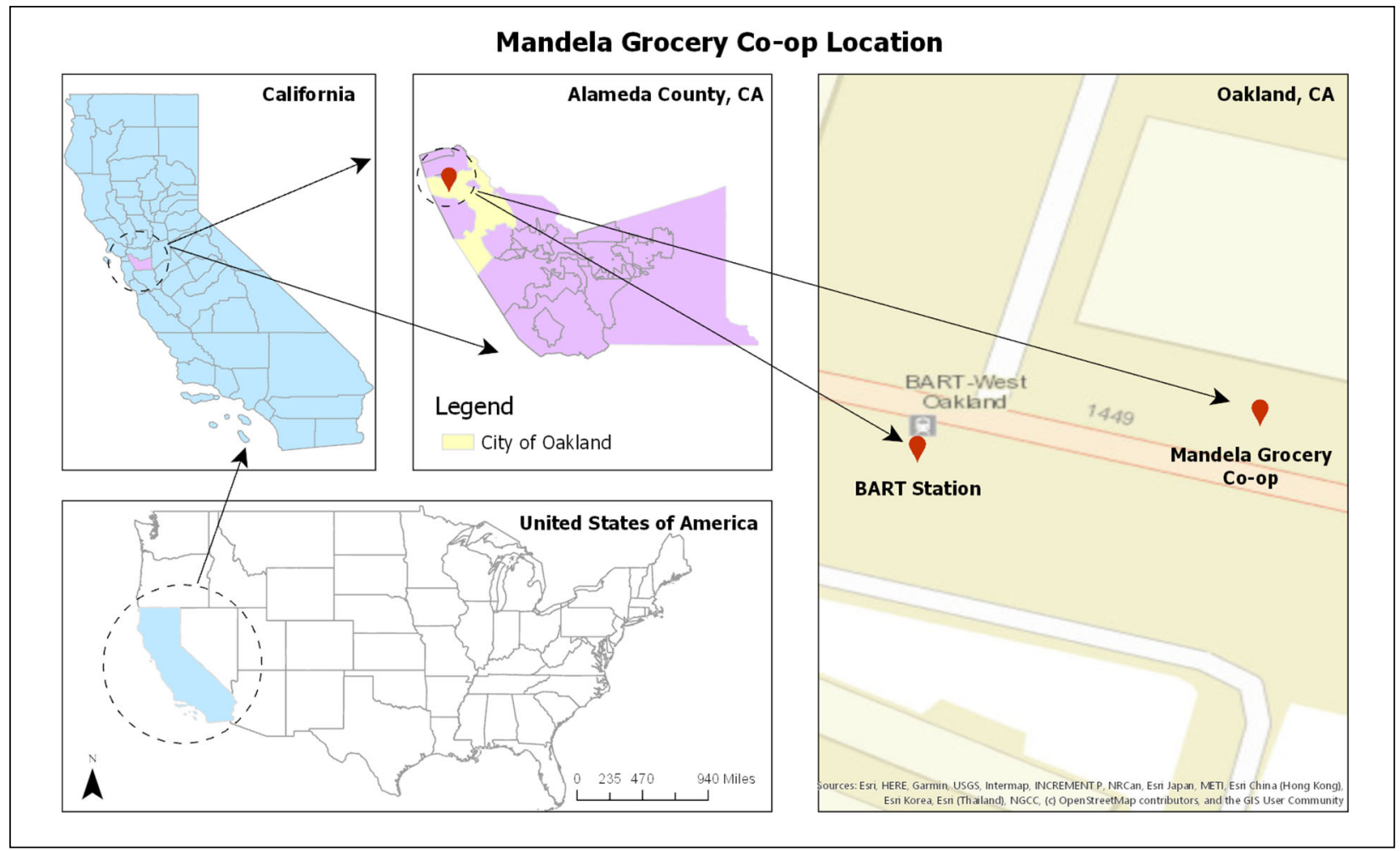

Sources: Fitzpatrick (2012); United States Census Bureau (2017a, 2017b, 2017c).

a Maps were created by using ArcGIS software by Esri. ArcGIS and ArcMap $^{\mathrm{TM}}$ are the intellectual property of Esri and are used herein under license. Copyright (C Esri. All rights reserved.

Indeed, the appeal of co-ownership and collective management helped attract Fike, who first encountered Mandela as a shopper and developed her relationship with the co-op over time. Becoming a worker-owner is not the work of a moment. It requires a commitment reflective of the spirit of cooperative economics and the dedication of smallbusiness ownership. Workers' hours are dependent on their own availability and schedules, but the coop prefers workers who can dedicate at least 15 hours per week. Workers must work at Mandela for at least one year or 1,000 hours, whichever comes first, before they earn the opportunity to buy in. The financial buy-in is US $\$ 2,000$, payable either as a lump sum or over time through payroll deduction. Benefits of ownership include a voice in how profits are distributed in profitable years. For instance, Fike shares that in one profit-making year, the worker-owners at Mandela decided to distribute a portion among worker-owners, put more money into the business, and then distribute money to other worker-owned businesses. They did this with the insight of experience; another coop, Rainbow Grocery Cooperative, had given Mandela US $\$ 20,000$, funding that had helped them succeed. They wanted to provide similar support to other organizations.

The complementary goals of public service and public ownership are generally evident in Mandela's practices and policies. In addition to filling the community's need for a full-service grocery store, to bolster community health through food, Mandela seeks to attract and serve recipients of SNAP and WIC benefits by offering these shoppers a $50 \%$ discount on everything that does not contain sugar, salt, or grease. Fike explains that this benefit is so well-known and popular that it attracts shoppers from outside the community as well, as does the idea of shopping at a Black-owned and operated business. However, shoppers at Mandela rep- 
resent a diverse group: both long-term West Oakland residents and newer residents, including White technology workers, anarchists, and vegans are among the regular clientele of Mandela (Henry, 2018).

Supporting the community and empowering others is a large part of Mandela's focus. It sponsors pop-up resource villages on the first Friday of every month. These pop-up resource villages, designed by a restorative justice architecture firm to bring people and resources together, celebrate Black culture and feature Black-owned businesses and resources. Participants can receive free haircuts, hear local music, engage in educational experiences, and simply enjoy the community., Its focus is also clear in its recent decision to part ways with its long-time fundraising partner, Mandela Marketplace, because of a shift in the shared vision of developing a space for partner nonprofit and worker-owned ventures to develop and thrive. As Mandela Marketplace shifted its focus toward making loans, Mandela Grocery Co-op decided to forego the opportunity to relocate to a much larger space in favor of dedicating its profits to the development of the community and other workerowned co-ops and businesses.

The community has seemed to embrace these efforts. Worker-owners at Mandela, for instance, know the history of the neighborhood and appreciate their own place in that history. Worker-owner James Bell imagines how proud his grandparents, who were residents during the economic prosperity of the Pullman Porter era, would be to see him working to revive the community (Mandela Partners, 2015). The challenge of foods being more expensive than what can be purchased at larger corporate outlets remains a part of the co-op reality, but online shopper comments demonstrate that nearly everyone, both shoppers and workerowners, understands what Mandela stands for: building wealth and helping the community. Many comments express sentiments that while prices may be higher than at other retailers, the benefit to the community makes the cost worthwhile (Yelp, n.d.-a).

Yesterday: Mandela Grocery Co-op's Oakland Roots The eastern part of the Bay Area in California,
Oakland (West Oakland in particular) embodies a rich history of race, economics, and political and community organizing in America. Once home to a thriving and influential Black middle class thanks to early unionization and wartime economic opportunities, post-war economic realities have left Oakland's economy decimated. In its heyday, many male residents in Oakland reaped the economic benefits of employment as Pullman Porters, because the city is home to the western terminus of the Central Pacific Railroad. The city was home to the first West Coast branch of the Brotherhood of Sleeping Car Porters, the union serving porters as well as cooks and domestic servants. One of its organizers and leaders, Cottrell Laurence (C. L.) Dellums, was a civil rights activist and labor leader.

Along with Black economic prosperity and social activism, Oakland's roots are rich in Black political and cultural activism. In 1966, the Black Panther Party for Self Defense was born in Oakland. Although he did not reside in Northern California, through his involvement in the Congress of Racial Equality (CORE) and the Student NonViolent Coordinating Committee, UCLA student Maulana (a.k.a. Ron) Karenga developed an activist agenda. As an influential Black cultural nationalist, Karenga created Kwanzaa, the African American alternative holiday to Christmas that is now popular throughout the U.S. Founded on seven principles known as Nguzo Saba, which Karenga characterizes as a communitarian African philosophy, Kwanzaa embraces several ideas that undergird the philosophy of worker-owned co-ops such as Mandela Grocery Co-op. Three particular principals of Nguzo Saba are evident in Mandela's work and mission:

- Kujichagulia (Self-Determination): To define and name ourselves, as well as to create and speak for ourselves.

- Ujima (Collective Work and Responsibility): To build and maintain our community together and make our brothers' and sisters' problems our problems and to solve them together.

- Ujamaa (Cooperative Economics): To build and maintain our own stores, shops, and other businesses and to profit from them 
together. (Kwanzaa, 2019, Section 2, Principles and Symbols, para. 5)

However, if one economic principle is consistent, it is change. Following World War II, both the loss of manufacturing jobs and the dwindling of the railroad as the hub of luxury travel contributed to the decline of Oakland as an economically thriving Black neighborhood. The decline continued to the point that the neighborhood, once a hub of Black culture and economic success, could not even claim access to a full-service grocery store at the beginning of the 21st century.

A look at recent numbers might suggest that Oakland is reclaiming its former economic prosperity, with the addition of 45,000 new jobs from 2010 to 2017 . Although the overall unemployment rate has declined sharply, the unemployment rates for Blacks at $9.7 \%$ and Latinos at $7.1 \%$ remain exorbitant compared to the $4.3 \%$ for White residents (Torres, 2017). This employment indicator, along with rising home and business costs, are harbingers of the type of gentrification that continually encroaches on Black communities in growing urban areas. But in this case, Oakland's history of community activism set the stage for a response.

As West Oakland was in desperate need of a store, Fike explains that the elders in the community, primarily women, organized and put out a call. Many people and groups interested in providing a store gathered at a meeting. Debate around whether it should be worker-owned or a sole proprietorship ensued, and the meeting inspired the founding of Mandela Marketplace, an organization that helped get Mandela Grocery Co-op started.

It took seven years to get Mandela Grocery Co-op up and running. In the meantime, two groups filled in the gap and provided fresh food for the community: a Black farmers market and a People's Grocery that began by delivering fresh food. Representatives of the People's Grocery attended the first meeting about bringing a grocery store to the area, but they did not want to be part of the food co-op. Now this group has a location and plans for a community market. It has already put US $\$ 2$ million worth of work into the building and needs an additional US $\$ 500,000$. While it will be a community market, it won't be a food co-op.
Fike explains: "We don't see ourselves competing with this store. We may share some customers because it is a store in the community, but our focus is primarily on the people in our community" (A. Fike, personal communication, October 24, 2018).

The spirit of collaboration and cooperation that defines Mandela Grocery Co-op now was won through hard work and compromise. Refused a lease at the large retail space they originally wanted, by the landlord who favored a big box 99 -cent store that also sought the space, Mandela Grocery Co-op's founders accepted the much smaller space next door and began working to build solutions to the problems in the community. Shortly after they opened the doors, Mandela Marketplace was formed as a partner nonprofit organization to support not only Mandela Co-op but also other initiatives based on food justice principles in the community.

\section{Tomorrow: Challenges and Opportunities for Mandela Grocery Co-op}

Nonprofit and grant-funded support, like that once provided by Mandela Marketplace, has helped keep Mandela Grocery Co-op up and running over the years. It currently funds the position of general manager, which was added when the logistics of running the store demanded it, according to Fike. But grant funding can be an uncertain foundation. In its efforts to build a customer base as strong as its grant funding, the co-op changed its name from its original choice, Mandela Food Co-op, to Mandela Grocery Co-op. Worker-owners believed this name change would illuminate its purpose to more people. Finally, after 10 years, (five of them spent striving against the challenge of limited space), Mandela Grocery Co-op had an opportunity to move to a larger space. It reached an agreement with the property owner to expand to the larger space the founders had originally wanted, the 99cent store having left the area as soon as the tax incentives ended (Kauffman, 2017a). The space would have provided opportunities for Mandela to support other community businesses, housing a community pharmacy, and sharing warehouse space with other food-distribution organizations. The move and associated renovations of the new space were expected to cost approximately US $\$ 1$ million. 
However, even with this widespread and consistent community goodwill fostered by the co-op's ideological focus on developing community wealth and its outreach efforts like the pop-up resource village, Mandela Co-op faces continual financial challenges. Although Mandela had become profitable, it could not fund the long-anticipated expansion. After several failed attempts to raise funds for the expansion, Mandela has chosen to shift direction instead. On a GoFundMe page once dedicated to raising funds for expansion, Mandela's workerowners explain that Mandela has given up the expansion plans as a result of funding challenges and is instead striving to meet a goal of US $\$ 200,000$ to update and improve its current location and offerings and to expand its support for other worker-owned co-op efforts in surrounding communities (GoFundMe, 2018).

Mandela's primary challenge moving forward, considering its strong community support, will be remaining profitable and developing its financial standing to become a consistent supporter of other worker-owned initiatives and organizations. Its place in the history of the community of Oakland both strengthens its foundation and demands continual advocacy and support for others.

\section{Conclusions}

Seward Community Co-op's expansion into the Bryant/Central neighborhoods and Mandela Grocery Co-op's activism in Oakland serve as just two of the many ways that food co-ops can take shape. Founded in the natural foods movement, Seward Co-op still was able to broaden its views and grow both internally and externally to navigate expansion into an originally resistant area. The growth and learning represented by that process are instructive for anyone undertaking community organizing efforts.

The story of Mandela is easy to celebrate in many ways. Still, while the community empowerment is undeniable, the recent unsuccessful effort to expand may seem disheartening. But just as the governance structure of a worker-owned cooperative has little in common with a corporate grocery store model, these organizations should not measure success in the same ways, either. Money, while clearly important, is not the bottom line for food co-ops. For the last 10 years, Mandela has provided a full-service grocery store to a community where there had been none. In an era of gentrification and growing disparities between economic growth for people of color and Whites in the Oakland area, Mandela represents a fiscally viable and profitable Black-owned business that creates community wealth and supports community health. With its newly articulated goal to focus on helping other ground-up organizations in surrounding communities, Mandela may well represent yet another trend in the ever-evolving landscape of American food co-ops.

Clearly, all food co-ops have to balance decisions about food costs and quality with what to stock and whom to hire. Beyond that, what these two case studies reveal is that co-op leaders must consider the ideological foundations and social, historical, and geographical contexts that will define the focus of their work, especially if they seek to reach the communities most in need of them, as these two co-ops did. Seward, originally a natural foods-based organization, enjoyed the benefit of middle- and upper-middle-class member/ owners who were more able to contribute money to the cause. However, to serve a diverse and less wealthy community, Seward had to devote much more effort to earning the trust and buy-in of the stakeholders in that community. Mandela, begun by community members to provide access to healthy food and build community wealth, was firmly embedded in the Oakland community from its inception. It enjoyed an advantage in community good-will and buy-in, but had to devote much more of its effort to raising capital and remaining financially afloat. While generalizing or suggesting algorithms for success is beyond the purview of these case studies, those interested in understanding or developing food co-ops might find a foothold in their ideological foundations as well as the social, historical, and geographical contexts.

\section{Acknowledgments}

We would like to thank the editors at JAFSCD and two anonymous JAFSCD reviewers for their helpful comments on earlier versions of this article. We are also indebted to George R. Johnson for creating the maps and graphs that appear in this article. 


\section{References}

Atkinson, S. R. (2016, April). What's missing from the discussion of "food deserts"? An analysis of discursive justice in "food desert" related articles in The New York Times, Chicago Tribune and The Los Angeles Times from 2008-2015. In P. Mendez \& K. Spreyer (Instructors), Environmental Sciences Senior Thesis Symposium. Symposium conducted by the University of California Berkeley Environmental Sciences Department. Retrieved from https://nature.berkeley.edu/classes/es196/projects/2016final/AtkinsonS_2016.pdf

Boarini, C. (2013, July 10). Community residents want to be heard, not 'saved' by new Seward Co-op in South Minneapolis. Twin Cities Daily Planet. Retrieved from https://www.tcdailyplanet.net/more-another-grocery-store-seward-co-op-listening-session-south-minneapolis/

Fitzpatrick, C. (2012) States_basic (Shape file). Redlands, CA: Esri. Retrieved on May 8, 2019, from https://www.arcgis.com/home/item.html?id=f7f805eb65eb4ab787a0a3e1116ca7e5\# overview

GoFundMe. (2018, March 22). Funding Healthy West Oakland. Retrieved December 27, 2019, from https://www.gofundme.com/f/mandelagrocery

Gordon Nembhard, J. (2014). Collective courage: A bistory of African American cooperative economic thought and practice. University Park: Pennsylvania State University Press.

Henry, S. (2018, July 9). An Oakland community grocery store feeds its people. KQED Food. Retrieved from https://www.kqed.org/bayareabites/129251/an-oakland-community-grocery-store-feeds-its-people

Kauffman, J. (2017a, March 21). Mandela Foods Co-operative set to expand into larger West Oakland space. SF Gate. Retrieved from https://www.sfgate.com/test-5-5-2017/article/Mandela-Foods-Co-operative-set-to-expand-into-11015430.php

Kauffman, J. (2017b, March 31) The rise of the modern food cooperative. SF Gate. Retrieved from https://www.sfgate.com/news/article/The-rise-of-the-modern-food-cooperative-11006896.php

Kwanzaa. (2019, June 25). Retrieved June 27, 2019, from https://en.wikipedia.org/wiki/Kwanzaa

Lindeke, B. (2015a, November 19). Neighborhood groups and Friendship Store agree to agree. Twin Cities Daily Planet. Retrieved from https://www.tcdailyplanet.net/neighborhood-groups-and-seward-friendship-store-agree-to-agree/

Lindeke, B. (2015b, July 10). The Seward Friendship Store sparks return of the co-op war. Twin Cities Daily Planet. Retrieved from https://www.tcdailyplanet.net/the-seward-friendship-store-sparks-return-of-the-co-op-war/

Mandela Partners. (2015, February 3). The Victory Garden's Edible Feast Episode 5 - The Bay Area [Video file]. Retrieved from https://www.youtube.com/watch?v=_2pOmZImI0Q

Minneapolis neighborhood profile: Bryant. (2011) Minnesota Compass. Retrieved from https://www.mncompass.org/ pdfs/neighborhood-profiles/Minneapolis-Bryant-102011.pdf

Minneapolis neighborhood profile: Central. (2011). Minnesota Compass. Retrieved from https://www.mncompass.org/ pdfs/neighborhood-profiles/Minneapolis-Central-102011.pdf

Minneapolis neighborhood profile: Seward. (2011). Minnesota Compass. Retrieved from https://www.mncompass.org/_pdfs/neighborhood-profiles/Minneapolis-Seward-102011.pdf

Minnesota Department of Transportation. (2018). City boundaries of Minnesota [Shape file]. St. Paul: Minnesota Department of Transportation. Retrieved on May 5, 2019, from https://gisdata.mn.gov/dataset/bdry-jurisdiction

Minnesota Department of Transportation. (2017). County boundaries of Minnesota. [Shape file]. St. Paul: Minnesota Department of Transportation. Retrieved on May 5, 2019, from https:/ / gisdata.mn.gov/dataset/bdry-counties

Neighborhoods of Minneapolis. (2018). In Wikipedia. Retrieved on October 30, 2018, from https://en.wikipedia.org/wiki/Neighborhoods of Minneapolis

Neighboring Food Co-op Association. (n.d.). What is a co-op? Retrieved from http://nfca.coop/definition/

Olsen, K. E. (1998). Minnesota food cooperatives records. Retrieved from http://www2.mnhs.org/library/findaids/00561.xml

Pagani, S. (2016, September 20). This cooperative grocery store wants to break the diversity mold. Civil Eats. Retrieved from https:// civileats.com/2016/09/20/this-minneapolis-cooperative-grocery-store-is-working-to-break-thediversity-mold/ 
Reid, S. (2012). Buying clubs: Diverse organizations with complicated relations to retail co-ops. Cooperative Grocer, 160(May-June), 8-10. Retrieved from https://www.grocer.coop/articles/buying-clubs

Reyes, D. (2015). How cooperative grocery stores are bringing food access to low-income neighborhoods. Retrieved January 15, 2020, from the Cooperative Development Institute website: http://cdi.coop/food-coops-food-deserts-low-income-communities/

Seward Community Co-op. (n.d.). SEED round-up program. Retrieved on January 16, 2020, from https://seward.coop/seed/

Seward Community Co-op. (2018, September). Classes and events calendar, September 2018. Retrieved on September 15, 2018, from https://seward.coop/news/calendar

Slocum, R. (2007). Whiteness, space and alternative food practice. Geoforum, 38(3), 520-533. https://doi.org/10.1016/i.geoforum.2006.10.006

Torres, B. (2017, November 30). Oakland struggles with keeping economic diversity. San Francisco Business Times. Retrieved from https://www.bizjournals.com/sanfrancisco/news/2017/11/30/oakland-diversity-jobsemployment-demographics.html

U.S. Census Bureau. (2017a). CA county boundaries [Shape file]. Suitland-Silver Hill, MD: U.S. Census Bureau. Retrieved on May 9, 2019, from https://data.ca.gov/dataset/ca-geographic-boundaries

U.S. Census Bureau. (2017b). CA places boundaries [Shape file]. Suitland-Silver Hill, MD: United States Census Bureau. Retrieved on May 9, 2019, from https://data.ca.gov/dataset/ca-geographic-boundaries

U.S. Census Bureau. (2017c). CA state boundary [Shape file]. Suitland-Silver Hill, MD: U.S. Census Bureau. Retrieved on May 9, 2019, from https://data.ca.gov/dataset/ca-geographic-boundaries

Us Organization. (1999). Nguそo Saba. Retrieved from http://www.us-organization.org/nguzosaba/NguzoSaba.html

Usher, K. M. (2015). Valuing all knowledges through an expanded definition of access. Journal of Agriculture, Food Systems, and Community Development, 5(4), 109-114. https://doi.org/10.5304/jafscd.2015.054.018

Wagner, J. (2017). Minnesota ranked 2nd-worst in U.S. for racial equality. Retrieved from https://minnesota.cbslocal.com/2017/08/22/minnesota-racial-inequality/

Yelp. (n.d.-a). Mandela Foods Cooperative [Reviews]. Retrieved on October 3, 2018, from https://www.yelp.com/biz/mandela-foods-cooperative-oakland

Yelp. (n.d.-b). Seward Community Co-op [Reviews]. Retrieved on September 20, 2018, from https://www.yelp.com/biz/seward-community-co-op-minneapolis-4

Zimbelman, K. (n.d.). A deeper dive into co-op history. Retrieved September 20, 2018, from the National Cooperative Growers Association website: http://strongertogether.coop/food-coops/history-of-co-ops/

Zitcer, A. (2015). Food co-ops and the paradox of exclusivity. Antipode, 47(3), 812-828. https://doi.org/10.1111/anti.12129 